\title{
Influence of ultrasound on germination, some biometric and physiological indices in Liquidambar styraciflua $L$.
}

\section{DANIELA SABINA POȘTA ${ }^{1}$, CIPRIAN RUJESCU ${ }^{2}$, TEODOR VINTIL $\breve{a}^{3 *}$, FLORIN SALA ${ }^{*}$}

Banat University of Agricultural Sciences and Veterinary Medicine "King Michael I of Romania" from Timisoara, No. 119 Calea Aradului Str., Timisoara, Romania

${ }^{1}$ Arboriculture and Landscape Architecture Discipline; ${ }^{2}$ Mathematic and Statistic Discipline; ${ }^{3}$ Biotechnology Department; ${ }^{4}$ Soil Science and Plant Nutrition Discipline

\begin{abstract}
This study evaluated the effect of ultrasound treatments on the percentage of germinated seeds and on seedlings during the first vegetation stages in Liquidambar styraciflua $\mathrm{L}$. Seeds treated with ultrasounds at varied intensities of the electric current and acoustic $1 \mathrm{~A}-0.44 \mathrm{~W} / \mathrm{cm}^{2}\left(\mathrm{~V}_{1}\right), 1.5 \mathrm{~A}-0.97 \mathrm{~W} / \mathrm{cm}^{2}\left(\mathrm{~V}_{2}\right), 2 \mathrm{~A}-1.74 \mathrm{~W} / \mathrm{cm}^{2}\left(\mathrm{~V}_{3}\right), 2.5 \mathrm{~A}-2.72 \mathrm{~W} / \mathrm{cm}^{2}\left(\mathrm{~V}_{4}\right)-$ were put to germinate together with a control variant $\mathrm{V}_{0}$. Compared to the control variant in which the percentage of germinated seeds (PGS) was $60 \%$, the seeds treated with ultrasounds reached $76 \%$ in the variant $\mathrm{V}_{4}$ and $95 \%$ in the variant $\mathrm{V}_{1}$. Biometric parameters and physiological indices showed higher values in the seedlings from seeds treated with ultrasounds (maximum in $\mathrm{V}_{1}$ ). Evolution of the leaf area and the features of the seedlings were described by polynomial functions under conditions of statistical safety. The logistic function described with fidelity the evolution of the leaf area in each individual leaf and in each variant: the highest value of the correlation coefficient was in $V_{1}$.
\end{abstract}

Keywords Seed germination, Liquidambar, logistic function, mathematic model, ultrasounds.

To cite this article: POȘTA AS, RUJESCU C, VINTILĂ T, SALA F. Influence of ultrasound on germination, some biometric and physiological indices in Liquidambar styraciflua L. Rom Biotechnol Lett. 2020; 25(2): 1369-1377. DOI: 10.25083/rbl/25.2/1369.1377

$\nabla$ *Corresponding author: FLORIN SALA, Banat University of Agricultural Sciences and Veterinary Medicine, Faculty of Agriculture, No. 119 Calea Aradului Str., 300645, Timişoara, Romania Tel.: +40 (21) 3182564 E-mail: florin_sala@usab-tm.ro 


\section{Introduction}

Seed germination is an important feature in plants breeding and some seed features determine the germination rate. Pre-germination treatments are applied in some seeds to reach higher germination percentages (BEWLEY [1]). Several studies have been reported approaching treatments in seeds with difficult germination: Acer pseudoplatanus L. (STEJSKALOVÁ \& al [2]), Albizia julibrissin Durazz., Albizia chinensis (Osbeck) Merrill, Albizia lebbeck (L.) Benth. (MEROU \& al [3]; MISSANJO \& al [4]; NONGRUM and KHARLUKHI [5]), Calanthe (R.Br.) hybrids (SHIN \& al [6]), Calanthe discolor Lindl. (MIYOSHI and MII [7]), Calotropis persica Gand. (FARAJOLLAHI \& al [8]), Faidherbia albida (Delile) A. Chev. (FREDRICK \& al [9]), Gleditschia triacanthos L., Caragana arborescens Lam., Laburnum anagyroides Med., Robinia pseudoacacia L. (ALADJADJIYAN [10]; POȘTA and CAMEN [11]), Larix europaea L., Picea glauca (Moench) Voss, Pinus banksiana Lamb., and Pinus resinosa Ait. (TIMONIN [12]; WEINBERGER and BURTON [13]), Pinus sylvestris L., Picea abies L. (PROKAZIN \& al [14]; RISCA \& al [15]), Sabal palmetto (Walt.) Lodd., Thrinax morrisii palms (H. Wendl.) C. Lewis \& Zona (DEWIR \& al [16]) etc. To stimulate germination, other studies approached pre-germination treatments in seeds known to have good germination rates: Avena sativa L., Secale cereale L., Triticosecale Wittm., Triticum aestivum L. (KRATOVALIEVA \& al [17]), Cicer arietinum L. and Citrullus lanatus (Thunb.) Matsum and Nakai (GOUSSOUS \& al [18]), Festuca arundinacea Schreb., Psathyrostaehys juncea Nevski (LIU \& al [19]), Helianthus annuus L. (MACHIKOWA \& al [20]), Hordeum vulgare L. (YALDAGARD and TABATABAIE [21]; YALDAGARD \& al [22]; MIANO \& al [23]), Lupinus varius L. (KARAGUZEL \& al [24]), Medicago sativa L., Brassica oleracea L. (KIM \& al [25]), Panicum virgatum L. (SARATH \& al [26]; WANG \& al [27]), Sorghum bicolor L. (PATERO and AUGUSTO [28]), Vicia faba L. (RUBTSOVA [29]), Zea mays L. (WEINBERGER \& al [30]), Zingiber officinale Roscoe (BALACHANDRAN \& al [31]).

Several pre-germination treatments have been established over the time and are currently applied to stimulate seed germination: soaking in warm or cold water (AKINOLA $\&$ al [32]; FREDRICK \& al [9]), chemical scarification by treating seeds with acids (HAYNES \& al [33]; AKINOLA \& al [32]; KIM \& al [25]; DEWIR \& al [16]; FREDRICK \& al [9]), mechanical scarification (FREDRICK \& al [9]), seed stratification (SHEN \& al [34]; POȘTA and CAMEN [11]), electromagnetic and microwave treatments (ALADJADJIYAN [10]; TALEI \& al [35]; SUDSIRI \& al [36]), magnetic field treatment (AFZAL \& al [37]), magnetic nanofluid treatments (SALA [38]) and one of the most common methods - ultrasound treatments (GORDON [39]; GOUSSOUS \& al [18]; KRATOVALIEVA \& al [17]; López-RIBERA and VICIENT [40]).

The goal of this study was to evaluate the influence of ultrasound treatments applied in seed of Liquidambar styraciflua L. on some indices related to seeds germination, biometric and physiological parameters in seedlings during their first stages of vegetation.

\section{Materials and Methods}

\section{Biological material}

The biological material used in our research is Liquidambar styraciflua L. The seeds were sampled from mature trees (around 20 years). The fruits were harvested at physiological maturity (ripe, green-brown colour), and dried on a platform, at room temperature in the laboratory of Arboriculture and Landscaping. The seeds were harvested, cleaned and selected manually. A total batch of 1,000 seeds was sampled and organized in small batches of 50 seeds for each variant in four replicates $(50 \times 4$ replicates $=200$ seeds/variant $\mathrm{x} 5$ variants $=1,000$ seeds). The seeds were stored in a refrigerator at $4{ }^{\circ} \mathrm{C}$ until use.

\section{Pre-germination treatment}

The treatment was applied in Liquidambar seeds by an ultrasound generator. The seeds were treated for 40 seconds in an electric current at variable intensities (1A, 1.5A, 2A and 2.5A), which determined specific acoustic intensities $\left(0.44 \mathrm{~W} / \mathrm{cm}^{2}, 0.97 \mathrm{~W} / \mathrm{cm}^{2}, 1.74 \mathrm{~W} / \mathrm{cm}^{2}\right.$, and $2.72 \mathrm{~W} / \mathrm{cm}^{2}$, respectively). After the treatment, the following trial variants were obtained:

untreated seeds - control $\left(\mathbf{V}_{\mathbf{0}}\right)$; treated seeds at several current intensities: 1A $\left(\mathbf{V}_{\mathbf{1}}\right) ; 1.5 \mathrm{~A}\left(\mathbf{V}_{\mathbf{2}}\right) ; 2 \mathrm{~A}\left(\mathbf{V}_{\mathbf{3}}\right)$, and $2.5 \mathrm{~A}$ $\left(\mathbf{V}_{4}\right)$. After the treatment, the seeds were incubated at $18-20^{\circ} \mathrm{C}$, for 30 days on watered filter paper in Petri dishes for germination.

\section{Biometric and physiological parameters}

To evaluate the influence of treatments on the seeds, measurements regarding the percentage of germinated seeds at the end of germination period were made. After thirty days of incubation, the resulted seedlings were transplanted in a substratum prepared by an equal mixture of peat and sand. Upon transplanting (May 17) $\left(\mathrm{t}_{1}\right)$, some biometric (stem diameter $-\mathrm{D}$, height $-\mathrm{H}$ ) and physiological parameters (root number $-\mathrm{RN}$, root length $-\mathrm{RL}$, leaf number $-\mathrm{LN}$, leaf size $-\mathrm{L}$ and $\mathrm{W}$, and chlorophyll content - Chl) were measured. Based on leaf size and on the model developed by SALA \& al [41], leaf area (LA) for each leaf and variant was calculated. Physiological indices were determined during dynamics between May 17 and September 17, 2016, every 30 days. Biometric parameters were determined at the beginning of the interval, May 17 being considered $t_{1}$, and at the end of the interval, September 17 considered $t_{2}$.

\section{Statistical analysis}

Trial data were analysed through the variance analysis, analysing of correlation and regression to evaluate the intensity of interdependence relationships between treatments and the values of biometric and physiological indices. Determining the coefficients of the regression functions was done using SPSS with regression/curve estimation. Determining the extreme values of real functions depending real variables (intensity of the electric current) was 
done using the classical methods of mathematical analysis based on differential calculus.

\section{Results and Discussion}

The ultrasound applied on Liquidambar seeds as pre-germination treatment increased the germination rate in Liquidambar seeds to $95 \%$ in the variant $\mathrm{V}_{1}$ and to $76 \%$ in the variant $\mathrm{V}_{4}$, compared to $60 \%$ in the control variant $\left(\mathrm{V}_{0}\right)$. The values of biometric and physiological parameters differed depending on seed treatment. The analysis of the values of biometric and physiological parameters shows that currents in the range of $1 \mathrm{~A}$, generate good results. Our aim is to set optimal current intensities values for Liquidambar seeds.

Explaining the different particular forms of functional dependence $\mathrm{y}=\mathrm{y}(\mathrm{x})$, where $\mathrm{y}$ is for plant features measured in $t_{1}$ and $t_{2}$, the form believed to best describe the phenomenon was a $3^{\text {rd }}$ degree polynom, $y=b_{0}+b_{1} x+b_{2} x^{2}+b_{3} x^{3}$. The decisive criterion was the value of correlation coefficients superior to $r=0.9$ in all situations, despite the fact that this functional dependence relationship ("factor - plant features") has the shape of a parabola (factor diminution or excess induce low effects, and between extreme values there is the optimum vale of the factor). Though the $3^{\text {rd }}$ degree polynom has two extreme points (a maximum and a minimum), the variation interval of the current ranging between $0 \mathrm{~A}$ and $2 \mathrm{~A}$ was of interest. Values superior to the measured limit had negative effects on plant development, and had no practical interest. Therefore, on the segment corresponding to the abscissa $\mathrm{x} \in[0,2]$ the $3^{\text {rd }}$ degree polynom ensured an accurate description of reality (Figure 1), the interval of maximum values. Thus, the maximum value of the function is the first root of the derivate, hence the relation (1):

$$
y^{\prime}=b_{1}+2 b_{2} x+3 b_{3} x^{2}=0 \Rightarrow x_{\text {max }}=\frac{-b_{2}-\sqrt{b_{2}^{2}-3 b_{1} b_{3}}}{3 b_{3}}
$$

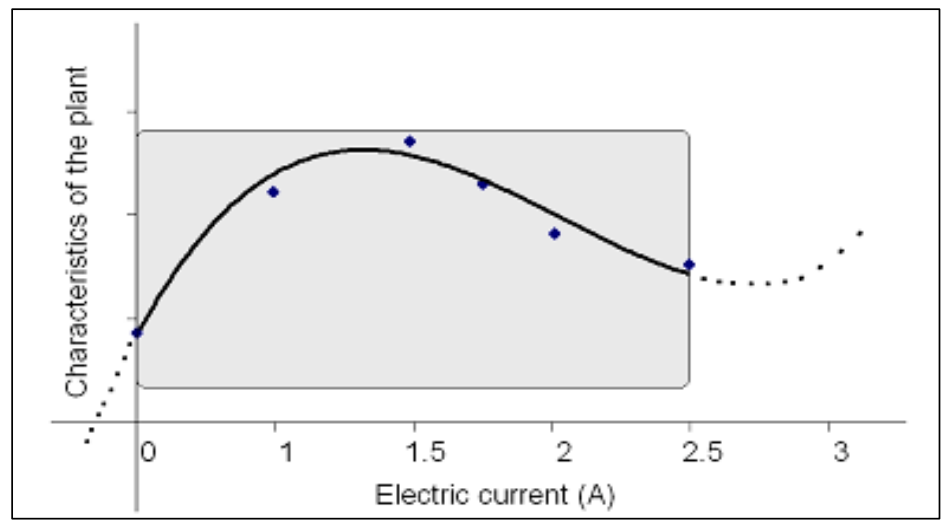

Figure 1. Model of functional dependence (based on Wolfram Alpha)

The experimental results and the coefficient values calculated with the SPSS soft are shown in Tables 1, where there are also optimum mathematical values (maximum values in this case) of the functions. Plant height $(\mathrm{H})$ reached a maximum for $0.77 \mathrm{~A}$ when measured initially $\left(\mathrm{Ht}_{1}\right)$, and for $0.82 \mathrm{~A}$ when measured finally $\left(\mathrm{Ht}_{2}\right)$. The evolution of the growth in seedling height $(\Delta \mathrm{H})$ is shown in Figure 2a.

Table 1. Mean values of plant features measured in $t_{1}$

\begin{tabular}{|c|c|c|c|c|c|c|c|c|c|c|c|c|}
\hline $\mathrm{A}$ & $\mathrm{Ht}_{1}$ & $\mathrm{Ht}_{2}$ & $\mathrm{Dt}_{1}$ & $\mathrm{Dt}_{2}$ & $\mathrm{RNt}_{1}$ & $\mathrm{RNt}_{2}$ & $\mathrm{RLt}_{1}$ & $\mathrm{RLt}_{2}$ & $\mathrm{LNt}_{1}$ & $\mathrm{LNt}_{2}$ & $\mathrm{LAt}_{1}$ & $\mathrm{LAt}_{2}$ \\
\hline 0 & 2.43 & 2.75 & 0.07 & 0.12 & 1 & 1.35 & 0.66 & 1.41 & 2 & 9 & 0.37 & 14.49 \\
\hline 1 & 6.46 & 9.83 & 0.35 & 0.39 & 1.4 & 5.00 & 4.55 & 12.87 & 10 & 18 & 68.45 & 233.50 \\
\hline 1.5 & 4.6 & 8.05 & 0.26 & 0.34 & 1.45 & 3.25 & 2.61 & 6.81 & 7.8 & 16 & 33.47 & 167.38 \\
\hline 2 & 3.01 & 4.14 & 0.13 & 0.19 & 1 & 1.65 & 1.41 & 2.68 & 4 & 12 & 5.27 & 58.13 \\
\hline \multirow[t]{2}{*}{2.5} & 2.68 & 3.60 & 0.11 & 0.16 & 1 & 1.35 & 1.13 & 2.20 & 3 & 10 & 1.50 & 35.48 \\
\hline & \multicolumn{12}{|c|}{ Trend line (polynomial - cubic) - $\mathrm{y}=\mathrm{b}_{0}+\mathrm{b}_{1} \mathrm{x}+\mathrm{b}_{2} \mathrm{x}^{2}+\mathrm{b}_{3} \mathrm{x}^{3}$} \\
\hline b0 & 2.436 & 2.726 & 0.079 & 0.118 & 0.993 & 1.354 & 0.677 & 1.440 & 1.986 & 8.987 & 0.480 & 14.089 \\
\hline $\mathrm{b} 1$ & 12.301 & 20.892 & 0.822 & 0.758 & 1.289 & 11.443 & 11.658 & 36.066 & 22.645 & 23.487 & 216.660 & 640.707 \\
\hline $\mathrm{b} 2$ & -10.642 & -17.083 & -0.684 & -0.591 & -1.013 & -10.012 & -10.131 & \begin{tabular}{|l|}
-32.042 \\
\end{tabular} & -18.225 & -17.763 & -192.190 & -526.740 \\
\hline \multirow[t]{3}{*}{ b3 } & 2.306 & 3.540 & 0.144 & 0.117 & 0.197 & 2.174 & 2.219 & 7.102 & 3.728 & 3.408 & 42.300 & 109.451 \\
\hline & \multicolumn{12}{|c|}{ Optimal electric current intensity (A) } \\
\hline & 0.77 & 0.82 & 0.80 & 0.86 & 0.84 & 0.75 & 0.77 & 0.74 & 0.83 & 0.88 & 0.74 & 0.81 \\
\hline
\end{tabular}

$\mathrm{Ht}_{1,2}$-Plant height, $\mathrm{Dt}_{1,2}$-Stem diameter, $\mathrm{RNt}_{1,2}$-Root number, $\mathrm{RLt}_{1,2}$-Root length, $\mathrm{LNt}_{1,2}$-Leaf number, LAt 1,2 -Leaf Area 

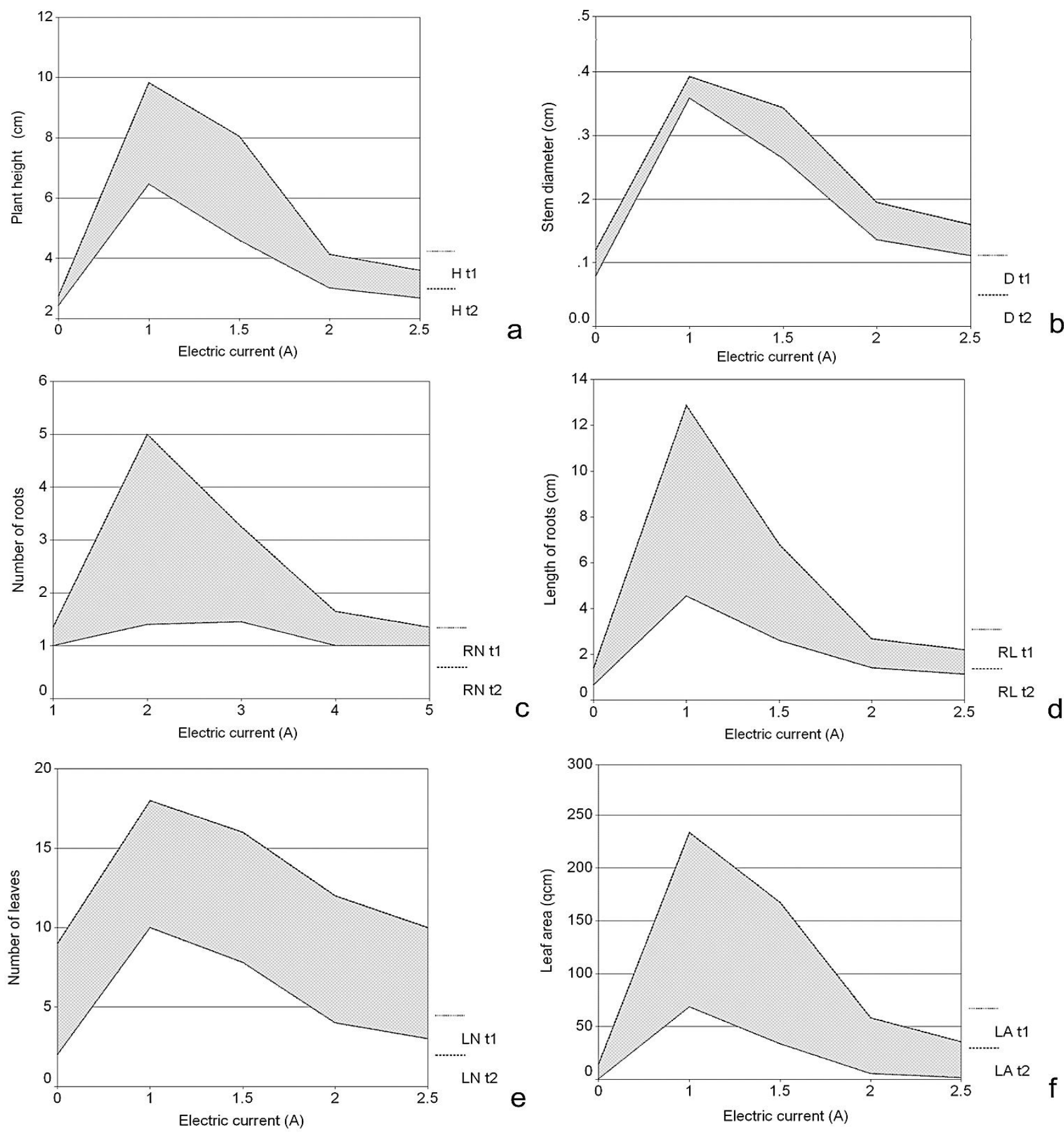

Figure 2. High-low diagramme (SPSS) describing the influence of current intensity on leaf area.

Stem diameter had maximum values for a current intensity between $0.80 \mathrm{~A}$ and $0.86 \mathrm{~A}$ (Figure 2b). Root number reached a maximum for $0.84 \mathrm{~A}$ upon the first measurement $\left(\mathrm{t}_{1}\right)$, and for $0.75 \mathrm{~A}$ upon the last measurement $\left(\mathrm{t}_{2}\right)$ (Figure $2 \mathrm{c}$ ). Maximum root length was with current intensity $0.77 \mathrm{~A}$ and $0.74 \mathrm{~A}$ upon both measurement times $\left(t_{1}\right.$, and $t_{2}$, respectively) (Figure $2 d$ ). Maximum leaf number in $\mathrm{t}_{1}$ was for a current intensity of $0.83 \mathrm{~A}$ and $0.88 \mathrm{~A}$ in $\mathrm{t}_{2}$ (Figure 2e). Leaf area was maximum for a current intensity of $0.74 \mathrm{~A}$ in $\mathrm{t}_{1}$ and for $0.81 \mathrm{~A}$ in $\mathrm{t}_{2}$ (Figure $2 \mathrm{f}$ ). Evolution of leaf areas can be a useful indicator in the evaluation of plant harmonious development. During the monitoring, 10 plants from each variant were evaluated periodically to evaluate the leaf number and the leaf area. The leaves were recorded chronologically; data processing presents the ascending trend of leaf area from the youngest to the oldest leaf. Leaves were noted in an ascending trend from the most recent to the oldest. Trial data as mean values of leaf number and leaf area in each variant at the final time are 
shown in Table 2. The newest leaves were expected to have a smaller leaf area because of the age that does not allow development, of the water, food and space competition induced by the existing leaves. Mean aged leaves had a better development than younger ones because of the longer time of existence and because the competition with the other laves was lower. Older leaves were the best developed, but their size was limited by some physiological and genetic aspects.

Therefore, it was possible to describe the phenomenon using as mathematical model the logistic function representing an exponential model with limited growth.
To do so, the trend line described by statistic data regarding the closeness of the logistic function data to the form of the relation (2) was evaluated:

$$
f(t)=1 /\left(b_{0} \cdot b_{1}{ }^{t}+1 / u\right)
$$

where $\mathrm{t}$ is the time axis;

$\mathrm{u}$ - upper bound specific to each group representing the rounded size of the oldest leaf;

$\mathrm{b}_{0}$ and $\mathrm{b}_{1}$, coefficients specific to the model and determined statistically using a SPSS with the regression/curve estimation procedure.

Table 2. Mean values of leaf number and leaf area per trial variant in $t_{2}$

\begin{tabular}{|c|c|c|c|c|c|c|c|c|c|}
\hline \multicolumn{2}{|c|}{$0 \mathrm{~A}$} & \multicolumn{2}{|c|}{$1 \mathrm{~A}$} & \multicolumn{2}{|c|}{$1.5 \mathrm{~A}$} & \multicolumn{2}{|c|}{$2 \mathrm{~A}$} & \multicolumn{2}{|c|}{$2.5 \mathrm{~A}$} \\
\hline No. & Leaf Area & No. & Leaf Area & No. & Leaf Area & No. & Leaf Area & No. & Leaf Area \\
\hline 1 & 0.93 & 1 & 2.33 & 1 & 1.00 & 1 & 0.67 & 1 & 1.57 \\
\hline 2 & 1.20 & 2 & 1.99 & 2 & 1.22 & 2 & 0.90 & 2 & 2.84 \\
\hline 3 & 0.97 & 3 & 2.93 & 3 & 1.72 & 3 & 1.73 & 3 & 2.90 \\
\hline$\ldots$ & $\ldots$ & $\ldots$ & $\ldots$ & $\ldots$ & $\ldots$ & $\ldots$ & $\ldots$ & $\ldots$ & $\ldots$ \\
\hline 8 & 2.42 & 17 & 22.10 & 15 & 20.81 & 11 & 8.09 & 9 & 4.25 \\
\hline 9 & 2.43 & 18 & 22.65 & 16 & 23.54 & 12 & 8.17 & 10 & 4.33 \\
\hline
\end{tabular}

*Leaf numbering was done from the newest leaf to the latest leaf

In each group, the square of the correlation coefficient (rsq.), the sig. and $\mathrm{F}$ values pointing to the reliability of the model, and the coefficients $b_{0}$ and $b_{1}$ were determined. The calculus was made for each variant depending on the current intensity $(0 \mathrm{~A}, 1 \mathrm{~A}, 1.5 \mathrm{~A}, 2 \mathrm{~A}, 2.5 \mathrm{~A})$. As expected, the logistic model described properly real phenomena. Rsq. values were high, pointing to a high, statistically ensured correlation, with sig. $<0.001$ values in each case and completed by values corresponding to F. Data presented in Table 3 show that higher rsq. values of the correlation coefficient were in the groups treated with ultrasounds, while the highest value was when treating with a current intensity of $1 \mathrm{~A}$ (rsq.=0.982). Moreover, monitoring the values of $\mathrm{F}$, confidence in the model was the highest in the variant $\mathrm{V}_{1}(\mathrm{~F}=853.7)$. Thus, for this current intensity, trial values pointed to a natural evolution well described with a model and, most important, predictable. The study focused on this aspect: the predictable character of a plant development can be an effective indicator of the seedling material quality.

Table 3. Indices and statistic coefficients for the logistic regression model used to characterize individual leaf area within trial variants

\begin{tabular}{|c|c|c|c|c|c|}
\hline & $0 \mathrm{~A}$ & $1 \mathrm{~A}$ & $1.5 \mathrm{~A}$ & $2 \mathrm{~A}$ & $2.5 \mathrm{~A}$ \\
\hline Rsq. & 0.847 & 0.982 & 0.965 & 0.974 & 0.945 \\
\hline Sig. & 0 & 0 & 0 & 0 & 0 \\
\hline F & 38.7 & 853.7 & 389.1 & 371.1 & 137.4 \\
\hline U & 2.5 & 23 & 24 & 8.5 & 4.5 \\
\hline b0 & 2.37 & 0.91 & 2.02 & 2.46 & 0.39 \\
\hline b1 & 0.57 & 0.68 & 0.65 & 0.58 & 0.66 \\
\hline
\end{tabular}

Knowing accurately the time evolution of growth and development physiological processes is an advantage that can be valorised directly. Moreover, successfully overlapping data on a functional model (given the rsq. values) also points to a lower number of anomalies in plant development compared to the cases in which trial values are removed from the function graph. Practically, a situation describing an anomaly can be exemplified as follows: though older, leaves have a smaller leaf area than medium-age leaves, anomalies observable in the graph as perturbations. Figure 3 shows the values observed, i.e. the logistic model for the plants from seeds treated with ultrasounds at $1 \mathrm{~A}\left(\mathrm{~V}_{1}\right)$. 


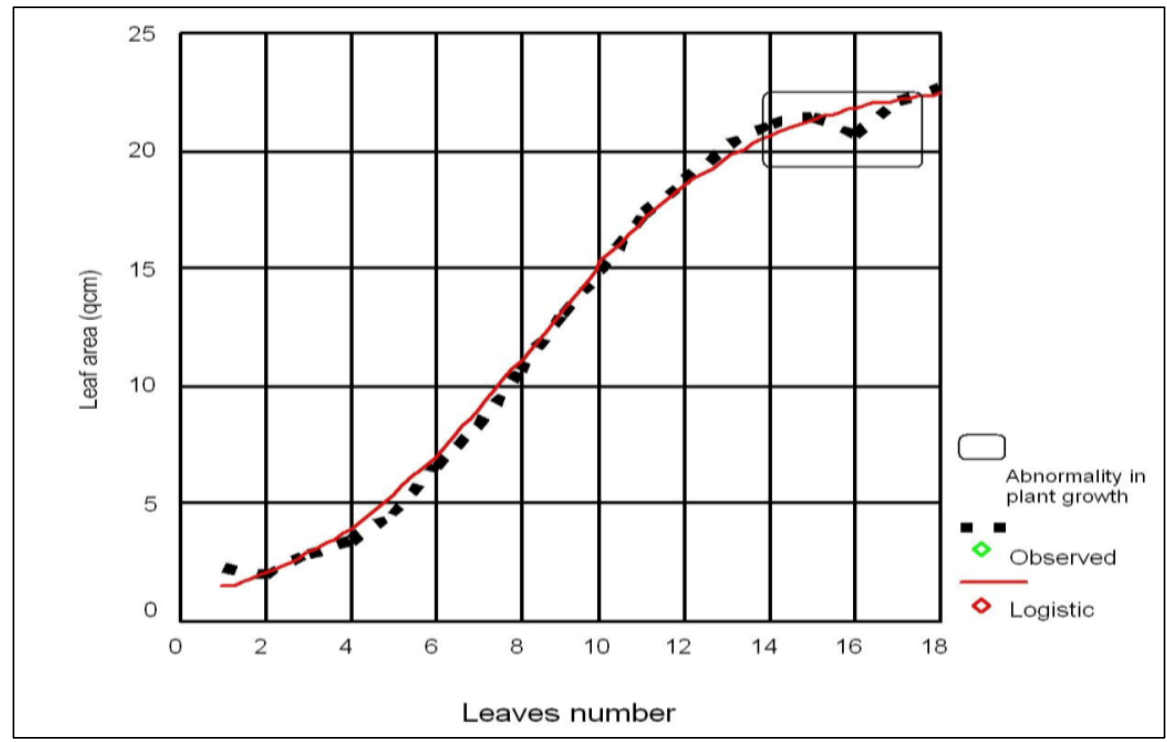

Figure 3. Values of foliar areas vs. logistic model in the plants treated with a current intensity of $1 \mathrm{~A}$ and abnormalities compared to the logistic model.

The observations described above point once more to qualitative aspects due to ultrasound treatment at $1 \mathrm{~A}$. Below are other details from the same level. Table 4 points to values of foliar area for the plants treated with the same current intensity, mans values of all measurements at intermediary times. Figure 4 shows the graphic distribution of foliar areas measured in the variant $\mathrm{V}_{1}$, pointing to a foliar area evolution trend similar from one leaf to another depending on the time they appeared and no matter the observation time. Dynamic evaluation of foliar area over the study period (120 days) in all variants points out variable growth rates of foliar area depending on the leaf number and leaf size in each variant. Mathematical description of foliar area was done by $2^{\text {nd }}$ degree polynomial statistically ensured: variant $\mathrm{V}_{0}$ (Control), equation (3),
$R^{2}=0.950 ;$ variant $V_{1}$, equation (4), $R^{2}=0.988 ;$ variant $V_{2}$, equation (5), $\mathrm{R}^{2}=0.955$; variant $\mathrm{V}_{3}$, equation (6), $\mathrm{R}^{2}=0.996$; variant $\mathrm{V}_{4}$, equation $(7), \mathrm{R}^{2}=0.998$.

$$
\begin{aligned}
& \mathrm{LA}_{V_{0}}=0.001603 x^{2}-0.08743 x+1.028 \\
& \mathrm{LA}_{V_{1}}=0.003158 x^{2}-0.111 x+2.332 \\
& \mathrm{LA}_{V_{2}}=0.004168 x^{2}-0.1037 x+7.612 \\
& \mathrm{LA}_{V_{3}}=0.004881 x^{2}-0.5494 \mathrm{x}+32.17 \\
& \mathrm{LA}_{V_{4}}=0.001854 x^{2}-1.146 \mathrm{x}+68.85
\end{aligned}
$$

where: $\mathrm{LA}_{\mathrm{V}_{0}}$ to $\mathrm{LA}_{\mathrm{V}_{4}}$ leaf area to the experimental variants; $\mathrm{x}$ - period in days (0-120 days).

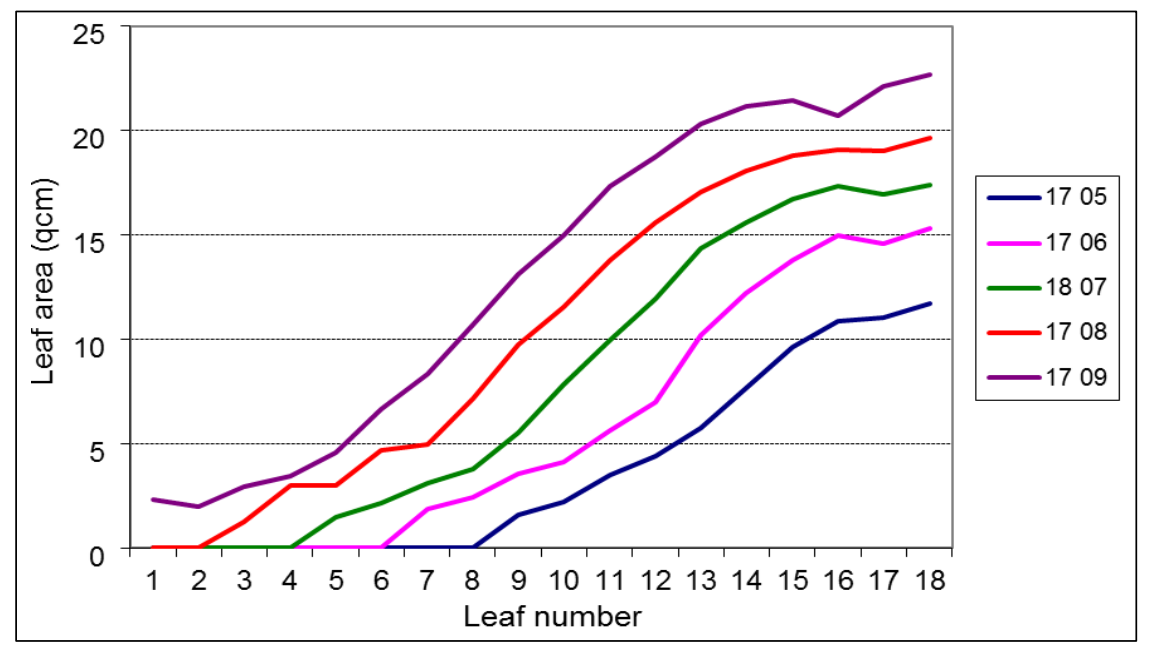

Figure 4. Values of foliar areas in the plants resulted from seed treated with a current intensity of $1 \mathrm{~A}$. 
Influence of ultrasound on germination, some biometric and physiological indices in Liquidambar styraciflua L.

Table 4. Values of foliar area in the plants treated with ultrasounds of $1 \mathrm{~A}\left(\mathrm{~V}_{1}\right)$

\begin{tabular}{|c|c|c|c|c|c|}
\hline \multirow{3}{*}{ Leaf number } & \multicolumn{5}{|c|}{ Foliar area in the time interval } \\
\cline { 2 - 6 } & 1705 & 1706 & 1807 & 1708 & 1709 \\
\cline { 2 - 6 } & Day $1\left(\mathrm{t}_{1}\right)$ & 30 days & 60 days & 90 days & 120 days $\left(\mathrm{t}_{2}\right)$ \\
\hline 1 & 0 & 0 & 0 & 0 & 2.33 \\
\hline 2 & 0 & 0 & 0 & 0 & 2.00 \\
\hline 3 & 0 & 0 & 0 & 1.26 & 2.93 \\
\hline$\ldots$ & $\ldots$ & $\ldots$ & $\ldots$ & 19.05 & 20.71 \\
\hline 16 & 10.86 & 14.97 & 17.34 & 19.02 & 22.10 \\
\hline 17 & 11.04 & 14.59 & 16.92 & 19.63 & 22.65 \\
\hline 18 & 11.74 & 15.32 & 17.39 & 186.35 & 233.50 \\
\hline Total LA & 68.45 & 105.77 & 144.20 & & \\
\hline
\end{tabular}

After obtaining different important effects of ultrasounds for agriculture, Gordon [39] presented, in his study, different ultrasound treatment methods meant to increase seed germinating ability. Later, other researchers tested the influence of ultrasound treatments aimed at increasing seed germinating ability. GOUSSOUS \& al [18] studied the influence of ultrasounds $(40 \mathrm{kHz})$ under laboratory conditions in four crop species (chickpea, pepper, watermelon and wheat) varying the duration of the treatment and germination temperatures. The authors obtained positive effects compared to the control var. in germination rate index and germination percentage, with variations from one species to another and with the duration of the treatment (recommended 15-minute treatment). MACHIKOWA et al [20] recorded a significant influence of ultrasounds on seed germination in sunflower, a positive effect also in seed vigour index (SVI), in root and seedling development. Other favourable results (YALDAGARD \& al [22], [42]; GOUSSOUS \& al [18]) of ultrasound have been reported on seed germination in some species of spontaneous flora, ornamental, or agricultural plants.

As for the way ultrasounds act on seeds, they claimed ultrasounds have a stress effect on the cells and tissues and that they change the structure and functions of biological molecules. They also cause changes in cellulose membrane with implications on absorption and water and nutrient ion transport (MACHIKOWA \& al [20]). Ion canals, as cellular molecular proteins making up permeability and selectivity barriers, are acted chemically or electrically and they have several specific features (TESTER [43]; CZEMPINSKI \& al [44]; WARD \& al [45]). Under the influence of ultrasound treatment, and based on observations regarding their effect on biological cells, tissues and molecules, it is possible to have changes in the pores and ion canals, particularly in the active ion canals, whose shape and size are controlled electrically and chemically through the difference in potential between membrane faces, with implications on the opening duration, of selectivity and of ion transport rate.

YALDAGARD \& al [22] communicated as an effect of ultrasound treatment in barley seeds the increase of porosity that facilitated a better hydration of the seeds with favourable effects on germination. They also estimated possible changes of the seed endosperm such as starch degradation that would generate an increase of hydrolysis reactions and of enzymes and enzymatic processes (alphaamylase) with favourable influence on germination and embryo growth (YALDAGARD \& al [42]; MACHIKOWA $\&$ al [20]). The influence of ultrasounds on certain enzymes (glycosidase, ATPase, etc.) of importance in industrial processes were communica-ted by other studies as well (BARTON \& al [46]; LIU \& al [47]). LIU \& al [19] recorded changes of the enzymatic activities (Peroxidase, Superoxide Dismutase) in Russian wild rye and fescue after the seeds were treated with ultrasounds. There were no positive effects of ultrasound treatments on germination percentage and on seedling growth in the two-studied species. Finding the proper intensity and duration of ultrasound treatment of seeds in each species is also a paramount issue. This study found as optimal a current intensity of $1 \mathrm{~A}$ and at higher values within the studied interval (up to 2.5A) there was reduction of favourable effects. Similar phenomena were presented in other studies (BARTON \& al [46]; LIU \& al [47]; PITT and ROSS [48]) mentioning damaging effects on cells and enzymatic activity with high ultrasound intensity. Seed germination is a much studied process and has also shown interest in other studies in relation to various factors of influence $[49,50]$. The logistic model described with accuracy the evolution of leaf area in each variant and facilitated particular deviation from the theoretical model of growth. A $3^{\text {rd }}$ degree polynomial model described the functional dependence of morphological and physiological parameters depending on the determining factor represented by the intensity of the electric current producing the ultrasounds; a $2^{\text {nd }}$ degree polynomial model described the dynamic evolution of total leaf area of each variant within the 120 days.

\section{Conclusion}

According to results, the seeds of Liquidambar styraciflua L. responded favourably to ultrasound treatments. The germination rate in seeds increased, the growth and development of obtained seedlings was improved during the first 120 days of cultivation. The most favourable effects regarding percentage of germinated seeds, morphological and physiological parameters in seedlings, have been found in variants treated with current intensities of $1 \mathrm{~A}$.

The logistic model described with accuracy the evolution of leaf area in each variant and facilitated 
particular deviation from the theoretical model of growth. A $3^{\text {rd }}$ degree polynomial model described the functional dependence of morphological and physiological parameters depending on the determining factor represented by the intensity of the electric current producing the ultrasounds; a $2^{\text {nd }}$ degree polynomial model described the dynamic evolution of total leaf area of each variant within the 120 days.

\section{Acknowledgements}

The authors thank to the staff of the Didactic and Research Base of the Banat University of Agricultural Sciences and Veterinary Medicine "King Michael I of Romania" from Timisoara, Romania to facilitate this research.

\section{References}

1. J.D. BEWLEY, Seed germination and dormancy, Plant Cell, 9(7), 1055, 1066 (1997).

2. J. STEJSKALOVÁ, I. KUPKA, S. MILTNER, Effect of gibberellic acid on germination capacity and emergence rate of Sycamore maple (Acer pseudoplatanus L.) seeds, Journal of Forensic Science, 61(8), 325, 331 (2015).

3. T. MEROU, I. TAKOS, E. KONSTANTINIDOU, S. GALATSIDAS, G. VARSAMIS, Effect of different pretreatment methods on germination of Albizia julibrissin seeds, Seed Science and Technology, 39(1), 248, 252 (2011).

4. E. MISSANJO, C. MAYA, D. KAPIRA, H. BANDA, G. KAMANGA-TOLE, Effect of seed size and pretreatment methods on germination of Albizia lebbeck, ISRN Botany, 060026 (2013).

5. A. NONGRUM, L. KHARLUKHI, Effect of seed treatment for laboratory germination of Albizia chinensis, Journal of Forestry Research, 24(4), 709, 713 (2013).

6. Y.K. SHIN, M.A. BAQUE, S. ELGHAMEDI, E.J. LEE, K.Y. PAEK, Effects of activated charcoal, plant growth regulators and ultrasonic pretreatments on in vitro germination and protocorm formation of Calanthe hybrids, Australian Journal of Crop Science, 5(5), 582, 588 (2011).

7. K. MIYOSHI, M. MII, Ultrasonic treatment for enhancing seed germination of terrestrial orchid, Calanthe discolor, in asymbiotic culture, Scientia Horticulturae, 35(1-2), 127, 130 (1988).

8. A. FARAJOLLAHI, B. GHOLINEJAD, H.I. JAFARI, Effects of different treatments on seed germination improvement of Calotropis persica, Advances in Agriculture, 2014, ID245686 (2014).

9. C. FREDRICK, C. MUTHURI, K. NGAMAU, F. SINCLAIR, Provenance and pretreatment effect on seed germination of six provenances of Faidherbia albida (Delile) A. Chev., Agroforestry System, 91(6), 1007, 1017 (2017).

10. A. ALADJADJIYAN, Influence of microwave irradiation on some vitality indices and electroconductivity of ornamental perennial crops, Journal of Central European Agriculture, 3(4), 271, 274 (2002).

11. D.S. POŞTA, D. CAMEN, Research regarding the influence of the preparing methods on seed germination on Gleditsia triacanthos L. Romanian Biotechnological Letters, 20(6), 11035, 11040 (2015).

12. M. TIMONIN, Effect of ultrasound on the germinaton of white spruce and jack pine seeds, Canadian Journal of Botany, 44, 113, 115 (1966).

13. P. WEINBERGER, C. Burton, The effect of sonication on the growth of some tree seeds, Canadian Journal of Forest Research, 11(4), 840, 844 (1981).

14. A.E. PROKAZIN, L.A. ATROSCHCHENKO, N.A. AVSIEVICH, G.D. VOROB'EVA, V.M. LUBYAGINA, V.I. GALKINA, Use of ultrasound and para-aminobenzoic acid for the pre treatment of forest seed, Lesnoe Khozyaǐstvo, 3, 46, 49 (1990).

15. I.M. RISCA, L. FARTAIS, P. STIUCA, Ultrasound effects contributions on the Norway spruce seeds germination (Picea abies (L.) Karsten), Genetics and Molecular Biology, VIII, 87, 88 (2007).

16. Y.H. DEWIR, M.E. EL-MAHROUK, Y. NOIDOO, Effects of some mechanical and chemical treatments on seed germination of Sabal palmetto and Thrinax morrisii palms, Australian Journal of Crop Science, 5(3), 248, 253 (2011).

17. S. KRATOVALIEVA, M. SRBINOSKA, G. POPSIMONOVA, A. SELAMOVSKA, V. MEGLIC, V. ANDJELKOVIC, Ultrasound influence on coleoptile length at Poaceae seedlings as valuable criteria in prebreeding and breeding processes, Genetika, 44(3), 561, 570 (2012).

18. S.J. GOUSSOUS, N.H. SAMARAH, A.M. ALQUDAH, M.O. OTHMAN, Enhancing seed germination of four crops species using an ultrasonic technique, Experimental Agriculture, 46, 231, 242 (2010).

19. J. LIU, Q. WANG, Đ. KARAGIĆ, X. LIU, J. CUI, J. GUI, M. GU, W. GAO, Effects of ultrasonication on increased germination and improved seedling growth of aged grass seeds of tall fescue and Russian wildrye, Scientific Reports, 6, 22403 (2016).

20. T. MACHIKOWA, T. KULRATTANARAK, S. WONPRASAID, Effects of ultrasonic treatment on germination of synthetic sunflower seeds, International Journal of Biological, Biomolecular, Agricultural, Food and Biotechnological Engineering, 7(1), 1, 3 (2013).

21. M.M.S. YALDAGARD, F. TABATABAIE, Application of ultrasonic waves as a priming technique for accelerating and enhancing the germination of barley seed: optimization of method by the Taguchi Approach, Journal of the Institute of Brewing, 114, 14, 21 (2008).

22. M. YALDAGARD, S.A. MORTAZAVI, F. TABATABAIE, Influence of ultrasonic on the germination of barley seed and its alpha-amylase, African Journal of Biotechnology, 7, 2456, 2471 (2008a).

23. A.C. MIANO, V.A. FORTI, H.F. ABUD, F.G. GOMESJUNIOR, S.M. CICERO, P.E.D. AUGUSTO, Effect of ultrasound technology on barley seed germination and vigour, Seed Science and Technology, 43(2), 297, 302 (2015). 
24. O. KARAGUZEL, S. CAKMAKCI, V. ORTACESME, B. AYDINOGLU, Influence of seed coat treatments on germination and early seedling growth of Lupinus varius L., Pakistan Journal of Botany, 36(1), 65, 74 (2004).

25. H.J. KIM, M.M. KUSHAD, X. FAN, Effects of ultrasound, irradiation, and acidic electrolyzed water on germination of alfalfa and broccoli seeds and Escherichia coli O157: H7, Journal of Food Science, 71(6), 168, 173 (2006).

26. G. SARATH, P.C. BETHKE, R. JONES, L.M. BAIRD, G. HOU, R.B. MITCHELL, Nitric oxide accelerates seed germination in warm-season grasses, Planta, 223, 1154, 1164 (2006).

27. Q. WANG, G. CHEN, H. YERSAIYITI, Y. LIU, J. CHI, C. WU, Y. ZHANG, X. HE, Modeling analysis on germination and seedling growth using ultrasound seed pretreatment in switchgrass, PLoS ONE, 7(10), e47204 (2012).

28. T. PATERO, P.E.D. AUGUSTO, Ultrasound (US) enhances the hydration of sorghum (Sorghum bicolor) grains, Ultrasonics Sonochemistry, 23, 11, 15 (2015).

29. I. RUBTSOVA, Effect of ultrasonics on seed germination and productivity of fodder beans, Biofizika, 12, 489, 492, (1967).

30. P. WEINBERGER, P. ANDERSON, L.S. DONOVAN, Changes in production, yield, and chemical composition of corn (Zea mays) after ultrasound treatments of the seeds, Radiation and Environmental Biophysics, 16(1), 81, 88 (1979).

31. S. BALACHANDRAN, S.E. KENTISH, R. MAWSON, M. ASHOKKUMAR, Ultrasonic enhancement of the supercritical extraction from ginger, Ultrasonics Sonochemistry, 13(6), 471, 479 (2006).

32. J.O. AKINOLA, A. LARBI, G.O. FARINU, A.A. ODUNSI, Seed treatment methods and duration effects on germination of wild sunflower, Experimental Agriculture, 36(1), 63, 69 (2000).

33. J.G. HAYNES, W.G. PILL, T.A. EVANS, Seed treatments improve the germination and seedling emergence of switchgrass (Panicum virgatum L.), HortScience, 32(7), 1222, 1226 (1997).

34. Z.X. SHEN, D.J. PARRISH, D.D. WOLF, G.E. WELBAUM, Stratification in switchgrass seeds is reversed and hastened by drying, Crop Science, 41, 1546, 1551 (2001).

35. D. TALEI, A. VALDIANI, M. MAZIAH, M. MOHSENKHAH, Germination response of MR 219 rice variety to different exposure times and periods of $2450 \mathrm{MHz}$ microwave frequency. Scientific World Journal, ID408026 (2013).

36. C.J. SUDSIRI, N. JUMPA, P. KONGCHANA, R.J. RITCHIE, Stimulation of oil palm (Elaeis guineensis) seed germination by exposure to electromagnetic fields, Scientia Horticulturae, 220, 66, 77 (2017).
37. I. AFZAL, K. MUKHTAR, M. QASIM, S. BASRA, M. SHAHID, Z. HAQ, Magnetic stimulation of marigold seed, International Agrophysics, 26(4), 335, 339 (2012).

38. F. SALA, Magnetic fluids effect upon growth processes in plants, Journal of Magnetism and Magnetic Materials, 201(1-3), 440, 442 (1999).

39. A.G. GORDON, The use of ultrasound in agriculture, Ultrasonics, 1(2), 70, 77 (1963).

40. I. LÓPEZ-RIBERA, C.M. VICIENT, Use of ultrasonication to increase germination rates of Arabidopsis seeds, Plant Methods, 13(31), 1, 6 (2017).

41. F. SALA, G.G. ARSENE, O. IORDĂNESCU, M. BOLDEA, Leaf area constant model in optimizing foliar area measurement in plants: A case study in apple tree, Scientia Horticulturae, 193, 218, 224 (2015).

42. M. YALDAGARD, S.A. MORTAZAVI, F. TABATABAIE, The effect of ultrasound in combination with thermal treatment on the germinated barley's alpha-amylase activity, Korean Journal of Chemical Engineering, 25, 517, 523 (2008b).

43. M. TESTER, Tansley Review No. 21 Plant ion channels: whole-cell and single channel studies, New Phytoloist, 114(3), 305, 340 (1990).

44. K. CZEMPINSKI, N. GAEDEKE, S. ZIMMERMANN, B. MÜLLER-RÖBER, Molecular mechanisms and regulation of plant ion channels, Journal of Experimental Botany, 50, 955, 966 (1999).

45. J.M. WARD, P. MÄSER, J.I. SCHROEDER, Plant ion channels: gene families, physiology, and functional genomics analyses, Annual Review of Physiology, 71, 59, 82 (2009).

46. S. BARTON, C. BULLOCK, D. WEIR, The effects of ultrasound on the activities of some glucosidase enzymes of industrial importance, Enzyme and Microbial Technology, 18(3), 190, 194 (1996).

47. Y. LIU, H. TAKATSUKI, A. YOSHIKOSHI, B.C. WANG, A. SAKANISHI, Effects of ultrasound on the growth and vacuolar $\mathrm{H}^{+}$-ATPase activity of aloe arborescens callus cells, Colloids and Surfaces B: Biointerfaces, 32, 105, 116 (2003).

48. W.G. PITT, S.A. ROSS, Ultrasound increases the rate of bacterial cell growth, Biotechnology Progress, 13, 232, 237 (2003).

49. R. CATANĂ, L. FLORESCU, A. SIMON-GRUIȚĂ, M. MITOI., Effect of the storage at low temperatures on the germination and antioxidant activity of Geum urbanum seeds, Romanian Biotechnological Letters, 23, 13599, 13606 (2018).

50. O. BORSAI, M. HASSAN, M. BOSCAIU, R.E. SESTRAS, O. VICENTE, Effects of salt and drought stress on seed germination and seedling growth in Portulaca, Romanian Biotechnological Letters, 23, 13340, 13349 (2018). 